\section{Freedom does not bring money}

SIR - Freedom does not bring money. This truth is trivial, but we in postCommunist countries meet it every day, and in its most concentrated form in science. Only a few years ago, scientists from mid- and East-European countries were treated as animals in cages to be looked at and mildly fed. Many friendly scientists in the free world tried to help them by invitations to the other side of Iron Curtain, paying their expenses at symposia and congresses, by gifts of scientific books, arranging the exchange of scientific journals and so on. Then, the representatives of the Communist regimes tried to end these contacts, not only from fear of the infiltration of adverse ideology, but also because proud socialist science could not go begging.

Now we are free, which is a good feeling. But freedom has not brought money to our countries. Especially in science, we are now even more povertystricken than before. And this situation is not realized even by our friends in economically strong countries. "It is apparent to me that $\mathrm{Dr} \mathrm{X}$ has not been able to keep up with developments in the subject over the last few years. I suggest that he should now, in the light of the great freedom that has come to Czechoslovakia, take advantage of the new situation and visit, particularly, the Agricultural University at Uppsala in Sweden. .." wrote a British friend in a review for the journal Photosynthetica, which I edit. But can Dr X really do that?

Let us omit the worst cases, such as the rest of Soviet Union or Romania, which still struggle both for real freedom and for bread. Take Czechoslovakia, generally understood abroad to be in a more or less acceptable economic situation. Parliamentary democracy functions, with all its advantages and shortcomings, and a clever policy keeps inflation within reasonable limits. But prices have increased by at least 50 per cent, while our (traditionally low) salaries have increased by only some 15 per cent. The government put an end to the black market in foreign currency by making the old black market exchange rate the official rate. Thus the life of foreign guests in Czechoslovakia is 2-3 times cheaper than before, but our visits to Western countries are 2-3 times more expensive.

The budgets of research institutes and universities are more or less the same as in Communist days, but the prices we pay for instruments, chemicals, literature and so on are much higher. This has already led, in the institutes of the Czechoslovak Academy of Sciences, to a 25 per cent reduction of staff, because otherwise we would not even have heat and light in our laboratories. At Czechoslovak universities, there has been no such reduction of staff; indeed, five new universities were founded in 1991. Their situation may be even worse than ours. But can scientists pay for themselves when the institutions cannot?

Here are a few examples of our present situation. My salary is one of the best in our institute, but at the present rate of exchange $(50 \mathrm{Kc}$ 's $=£ 1)$ I get something like $£ 100$ per month after deducting tax (a postgraduate student gets $£ 40$ and a science beginner some $£ 60$ ). It is not difficult to calculate that my membership subscription to the American Society of Plant Physiologists, including the journals Plant Physiology and The Plant Cell, costs more than my monthly salary, a week's stay in the United Kingdom at a symposium with fees about three times my monthly salary, buying a PC half a year's salary and so on. Most of us are accustomed to having only a few pounds in our pockets, eating fast food and even sleeping in a laboratory when abroad, and we do not complain. Nevertheless, the travelling costs are possible only by Czechoslovak bus (Prague-Paris-Prague for a third of my monthly salary). It is much more expensive to use a train (the same trip second class without a sleeping berth costs more than a month's salary) or plane (more than two months' salary). So it is almost impossible to travel overseas.

So our newly acquired freedom is somewhat illusory and the wish of many scientist for better knowledge, contacts and common research projects still remains in the realm of dreams. I ask our old and new scientific friends to realize that freedom does not necessarily bring a horn of plenty and to support us in the same way - or better - than before. We have to return to the world science community as soon as possible, and we are in no better an economic situation than the developing countries you often help.

Institute of Experimental Botany, Czechoslovak Academy of Sciences, 16000 Prague 6,

Czechoslovakia

SIR - We appeal on behalf of the recent Congress of the Soviet Astronomical Society, which was established in 1990 and which unites about 400 career astronomers. It is the only independent organization to represent the professional interests of about 3,000 Soviet astronomers. We wish to draw attention to the rapidly deteriorating situation of astro- nomy in our country (by which we mean the whole territory of the former Soviet Union, including the now independent republics).

Astronomy is likely to become one of the first victims of the economic crisis, if only because it involves considerably fewer people than other sciences. Financial support for many scientific projects has almost ceased. Our small community may collapse in a few months without immediate support. We also have great difficulty in getting funds for subscriptions to astronomy periodicals.

Nevertheless, we have able theoreticians as well as observers, and there exist a number of unique instruments and small and medium-sized telescopes over a large range of longitude. Mutually profitable co-operative studies with astronomers elsewhere could be developed in the fields of theoretical astronomical and astrophysical research. Compilation of astronomical catalogues is a possibility, as well as different branches of observational works, including those that do not require sophisticated technology but need a long timespan, such as variable star and some extragalactic researches. Joint investigations and grants to help to overcome intellectual isolation from the scientific community may be the best way of helping us to survive for the next several critical years and to conserve our potential for the benefit of the world astronomical community.

On behalf of the Congress of the Soviet Astronomical Society, we hope to hear from institutions or individuals willing to help to organize forms of cooperation and support for Soviet astronomy and astronomers.

N. G. BOCHKAREV

A. D. CHERNIN

YU. N. EFREMOV

N. N. SAMUS

A. V. ZASOV

Soviet Astronomical Society,

Sternberg Astronomical Institute,

13 Universitetskij Prospect,

119899 Moscow, USSR

(Fax: 0959390126 )

\section{Left out}

SIR - Lists such as those of scientific centennials and half-centennials (J. L. Heilbron and W. F. Bynum, Nature 355, $11 ; 1992)$ are not intended to be exhaustive but I think the article is a little unfair to the memory of Henry Walter Bates, discoverer of batesian mimicry, who died in London on 16 February 1892.

Department of Physiology,

Michigan State University,

East Lansing,

Michigan 48824-1101, USA 